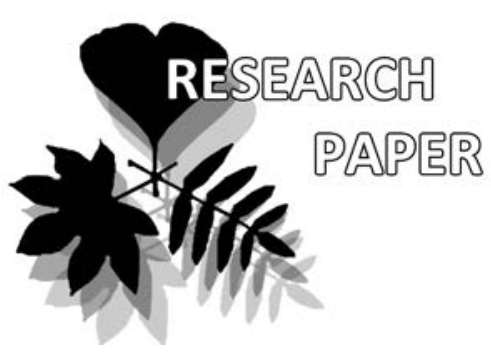

Anton G. Shiryaev

e-mail: anton.g.shiryaev@gmail.com

Institute of Plant and Animal Ecology, Ural Branch RAS, Ekaterinburg, Russia

Manuscript received: 18.05 .2020

Review completed: 14.10 .2020

Accepted for publication: 30.10 .2020

Published online: 03.11.2020

\section{Climate continentality increases the beta diversity of macrofungal communities}

\author{
Anton G. Shiryaev
}

\begin{abstract}
A B S T R A C T
The data on changes in the diversity of the model group of fungi of the middle boreal subzone in Eurasia are summarized. From Finland to Yakutia, with increasing climate continentality, the $\alpha$ - and $\gamma$-diversity of fungal communities decreases, but the $\beta$-diversity increases $1.7-5$ times, which indicates an increase in the spatial isolation of local fungal communities. Similar trends have been found for other high-latitude regions: tundra and forest-tundra.
\end{abstract}

K e y w o r d s : Eurasia, Siberia, biogeography, climate, clavarioid fungi, distribution, diversity, ecology

\section{P E 3 Ю M E}

Ширяев А.Г. Континентальность кмимата увемичивает бета-разнообразие сообществ грибов. Обобщены данные по изменению разнообразия модельной группы грибов среднетаежной подзоны Евразии. От ФинАяндии Ао Якутии, с ростом континентальности климата снижается $\alpha$ - и $\gamma$-разнообразия сообществ грибов, а $\beta$-разнообразие возрастает в $1,7-5$ раз, что свидетельствует об усилении пространственной изоляции Аокальных сообществ грибов. Аналогичные тренды установлены и Аля Аругих высокоширотных регионов - тундровых и лесотунаровых.

КАючевые слова: Евразия, Сибирь, биогеография, климат, распространение, разнообразие, клавариоидные грибы, экология
Studying the spatial trends of biodiversity at various scales in connection with the ongoing climate change and the growth of economic activity is one of the leading problems of biogeography and ecology (Lomolino et al. 2010). In connection with global changes, a new environmental protection methodology is developed that takes into account the dynamics of the spatial distribution of species (Mateo et al. 2016). However, such studies are carried out by the example of plants and animals, while the distribution of the Kingdom Fungi has been studied extremely poorly. Although it is common knowledge that macrofungi are considered as important natural resources in ecosystems owing to their major role in decomposition, nutrient cycling and mutualistic associations with other organisms.

Traditionally, the change in mycobiota diversity is studied by the example of two spatial gradients: latitudinal and altitudinal. Typically, with this approach, a clear decrease in inventory diversity is recorded in localities ( $\alpha$-diversity) and areas ( $\gamma$-diversity) as one approaches the arctic or alpine borders of the forest (Mukhin 1993, Bocharnikov 2015). As regards the third-longitude gradient of climatic continentality, information is extremely scarce. At the same time, Eurasia is the largest continent, where changes in the continental climate, from oceanic to ultracontinental, are most prominently represented. Along the continental gradient, from the Atlantic and Pacific coasts to the direction of Yakutia and Transbaikalia, the severity of the climate increases, the edaphic parameters and structure of the vege- tation change, the $\alpha$ - and $\gamma$-diversity of the brio- and lichen flora of the zonal habitats, various fauna groups decrease (Ignatov 1993, Urbanavichus 2009, Mordkovich 2014).

A change in another important characteristic, $\beta$-diversity, which reflects the differentiation of species composition, has been studied very poorly. For many groups of vascular plants, the peak of $\beta$-diversity falls on equatorial latitudes, although for Northern Eurasia there are examples of growth of this parameter in the direction of the upper, arctic or arid borders of the forest zone, i.e., to ecotone zones of forest vegetation with tundra and steppe (Bocharnikov 2015). For cryptogams, with the prevailing $\beta$-diversity growth paradigm decreasing with latitude, more and more information has appeared in recent decades indicating that, for example, the $\beta$-diversity of the European moss floras grows northward (Mateo et al. 2016).

One of the problems of the low level of knowledge on the principles of the spatial distribution of macromycete diversity is that only about $10 \%$ of the potential number of planet species have been identified at the moment, and many regions of the planet still remain mycological "blank spots". A possible way out of this situation is to investigate the distribution of a well-studied, model group of macromycetes - clavarioid fungi (Basidiomycota). This group of fungi is one of the best studied in Russia and neighboring countries (Shiryaev 2014, 2018).

The spatial distribution of the taxonomic and eco-morphological structure of the clavarioid fungi of the boreal 
zone of Eurasia has been studied quite well (Shiryaev 2014). It has been found that the prevalence of widespread species in the tundra, taiga and steppe regions with an almost complete lack of narrow areal distinctions distinguishes the inland continental "plain" mycobiota from the oceanic one (Mukhin 1993, Shiryaev 2014). In general, according to the main taxonomic and ecological-geographical parameters, there is a very clear distinction between the mycobiota from the oceanic and continental zones. For example, in case of the clavarioid fungi of the Urals, $\beta$-diversity estimated by various methods reaches the maximum levels on the steppe and arctic borders of the forest zone, but this indicator is lower in the richest hemiboreal and broad-leaved forests (Shiryaev 2018).

The aim of the work is to characterize the changes in the $\beta$-diversity of clavarioid fungi communities along the gradient of the climatic continentality of Eurasia. We have tested the hypothesis that, as continentality increases, the fungal communities become more even in species composition. Thus, $\beta$-diversity is reduced.

\section{MATERIAL AND METHODS Climate continentality in Eurasia}

The Siberian anticyclone controls weather conditions on the vast areas of Siberia and supports formation of continental climate in the inner part of northern Asia. The continental climate is characterized by sharp contrast between the summer and winter temperatures and strongly affects the distribution and development of vegetation and, respectively, nutrition of heterotrophs, their ontogenesis rhythms, and combinations of biota species. The continental gradient is expressed in all radial directions from the center of Siberian anticyclone activity, in Eastern Siberia. This study is focused on a gradient of continentality from the center of Eastern Siberia to the west to the Atlantic coast of Fennoscandia.

The farther from the center of the Siberian anticyclone to the west, the weaker its influence. Northern Atlantic cyclones soften the dry and cold continental air contributing to the formation of clouds, thaws and precipitation. The invasion of warm and moist air masses from the west is very common in Northern and Eastern Europe, not every year in the Urals, rarely in Western Siberia, but never in
Eastern Siberia. Due to the Siberian anticyclone the mean temperature of January changes from $-38,6^{\circ} \mathrm{C}$ in Yakutsk to $+1,8^{\circ} \mathrm{C}$ in Norway (Bodø). The absolute minimum temperature in the same direction decreases from $-64.4^{\circ} \mathrm{C}$ to $-15^{\circ} \mathrm{C}$ (Table 1). The difference of mean temperature of July over a distance of 7 thousand kilometers from Yakutia to Norway is only $5^{\circ} \mathrm{C}$, but the degree day temperatures $\left(>10^{\circ} \mathrm{C}\right)$ in those locations are 1050 to $2550^{\circ} \mathrm{C}$ respectively. Thus the Siberian anticyclone shortens the growth period of plants and, hence, heterotrophic organisms inside of the continent, to 68 days, while in Norway this parameter reaches 310 days (Fick \& Hijmans 2017).

An integrated assessment of changes in climatic conditions from the interior of the continent to its oceanic margins is illustrated by distribution of the index of continentality. Here, we use the Conrad's continentality index (Ic), commonly used by different authors (Tuhkanen 1984, Talbot \& Meades 2011):

$$
I c=1.7 \mathrm{~A} / \sin (\varphi+100)-14 \text {, }
$$

where, $A-$ is an average annual temperature amplitude of the coldest (January) and warmest (July) months, $\varphi-$ latitude. The index value is expressed as a percentage (\%) of the maximum value and is displayed on Figure 1.

\section{Study sites description}

The middle boreal subzone has been studied along the way of the Atlantic transport of air masses, from the coast of the Gulf of Bothnia of the Baltic Sea (Oulu, Finland) to Yakutia (Yakutsk and Churapcha, Russia). The Atlantic vector was selected due to its greater length $(6200 \mathrm{~km})$

Table 1. Climatic parameters along middle boreal subzone in Norway (Bodø) and Yakutia (Yakutsk).

\begin{tabular}{lcc}
\hline \multirow{2}{*}{ Climatic parameters } & \multicolumn{2}{c}{ Locations } \\
\cline { 2 - 3 } & Bodø & Yakutsk \\
\hline mean annual temperature $\left({ }^{\circ} \mathrm{C}\right)$ & +4.6 & -9.1 \\
mean temperature in January $\left({ }^{\circ} \mathrm{C}\right)$ & +1.8 & -38.6 \\
minimum temperature $\left({ }^{\circ} \mathrm{C}\right)$ & -15 & -64.4 \\
degree days $\left(>10^{\circ} \mathrm{C}\right)$ & 2550 & 1050 \\
annual precipitation $(\mathrm{mm} /$ year$)$ & 1070 & 217 \\
winter precipitation $(\mathrm{mm})$ & 315 & 27 \\
number of days with snow & 8 & 157 \\
number of frost-free days & 310 & 68 \\
\hline
\end{tabular}

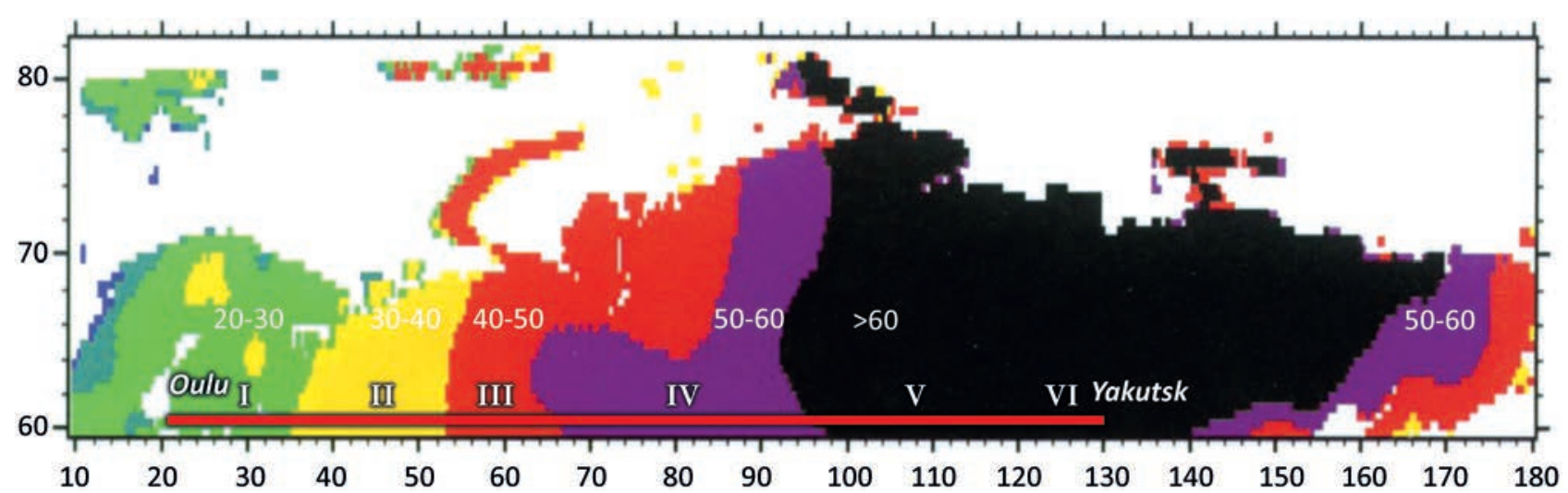

Figure 1 Conrad's index of continentality $(0-100)$ and continentality sectors (I-VI, see explanation in the text) in the Eurasian North based on the $0.5^{\circ}$ gridded monthly temperature data for the years 1991-1998). Red line is transect between Oulu and Yakutsk. Map is modified from Skre et al. 2002 
compared with the Pacific $(1100 \mathrm{~km})$ and the prevalence of lowland territories, while the east of Yakutia is mostly represented by mountainous landscapes. The species richness of fungi was studied on a macroscale: in six sectors of continentality (approximatelly $100000 \mathrm{~km}^{2}$ each): I - maritime (Fennoscandia), II - subcontinental plain (Eastern Europe), III - subcontinental hills (Urals), IV - continental plain (Western Siberia), V - continental hills (Central Siberia), VI - ultracontinental (Eastern Siberia).

On the mesoscale, diversity was studied in 43 localities, each with an area of $100 \mathrm{~km}^{2}$, nearly equally distributed in six continental sectors (Table 2). European sectors are smaller in area compared to Siberian ones. In this regard, six to seven localities were studied in the European sectors, and eight in the Siberian sectors.

Temperature and humidity were estimated for four localities in each sector of continentality according to data from ten loggers (40 loggers in each sector) installed at the soil-litter contact in various sites in relief. Therefore, along the entire transect, we received data from a total of 240 loggers. In Table 1, the environmental parameters and the continentality index are calculated from the logger records.

The author develops the CLAVARIA WORD database, which includes information on the finds of clavaroid fungi in the world based on numerous personal collections, published data in the literature, herbarium materials from

Table 2 Longitudinal sectors, names, distribution and coordinates of 43 localities studied in the middle boreal zone of Eurasia (localities distributed along longitude)

\begin{tabular}{|c|c|c|c|}
\hline No & Locality & Distribution & Coordinates \\
\hline \multicolumn{4}{|c|}{ Sector I FENNOSCANDIA } \\
\hline 1 & Oulu & Finland, Northern Ostrobothnia, surrounds of Oulu town & 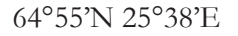 \\
\hline & Hiidenportti & Finland, Kainuu, Hiidenportti National Park and its surrounds & $63^{\circ} 52^{\prime} \mathrm{N} 29^{\circ} 00^{\prime} \mathrm{E}$ \\
\hline & Tolvoyarvi & $\begin{array}{l}\text { Karelia Republic, Suoyarvi area, surrounds of Tolvoyarvi village, western shores of } \\
\text { Tolvoyarvi lake }\end{array}$ & $62^{\circ} 17^{\prime} \mathrm{N} 31^{\circ} 27^{\prime} \mathrm{E}$ \\
\hline 4 & Kolatselga & Karelia Republic, Pryazhinsky area, surrounds of Kolatselga village & $61^{\circ} 40^{\prime} \mathrm{N} 32^{\circ} 13^{\prime} \mathrm{E}$ \\
\hline 5 & Veshkelitsa & Karelia Republic, Pryazhinsky area, surrounds of Veshkelitsa village & $61^{\circ} 55^{\prime} \mathrm{N} 32^{\circ} 48^{\prime} \mathrm{E}$ \\
\hline & Kivach & Karelia Republic, Kivach Nature Reserve & $62^{\circ} 15^{\prime} \mathrm{N} 33^{\circ} 59^{\prime} \mathrm{E}$ \\
\hline \multicolumn{4}{|c|}{ Sector II EASTERN EUROPE } \\
\hline 7 & Sheleksa & Arkhangelsk Region, Plesetsk area, surrounds of Sheleksa village & $62^{\circ} 51^{\prime} \mathrm{N} 40^{\circ} 22^{\prime} \mathrm{E}$ \\
\hline 8 & Ukhmenga & Arkhangelsk Region, Verkhnetoemski area, surrounds of Ukhmenga village & $62^{\circ} 26^{\prime} \mathrm{N} 45^{\circ} 20^{\prime} \mathrm{E}$ \\
\hline & Vasilyevskoye & Arkhangelsk Region, Kotlas area, surrounds of Vasilyevskoye village & $60^{\circ} 55^{\prime} \mathrm{N} 46^{\circ} 19^{\prime} \mathrm{E}$ \\
\hline 10 & Fominski & Arkhangelsk Region, Vilegodski area, surrounds of Fominski village & $61^{\circ} 16^{\prime} \mathrm{N} 48^{\circ} 44^{\prime} \mathrm{E}$ \\
\hline 11 & Chukhlam & Komi Republic, Sysola area, surrounds of Chukhlam village & $61^{\circ} 11^{\prime} \mathrm{N} 50^{\circ} 10^{\prime} \mathrm{E}$ \\
\hline 12 & Keross & Perm Region, Gainy area, surrounds of Keross village & $60^{\circ} 45^{\prime} \mathrm{N} 52^{\circ} 52^{\prime} \mathrm{E}$ \\
\hline & Pil'va & Perm Region, Cherdyn' area, surrounds of Pil'va village & $60^{\circ} 50^{\prime} \mathrm{N} 55^{\circ} 52^{\prime} \mathrm{E}$ \\
\hline \multicolumn{4}{|c|}{ Sector III URAL } \\
\hline & Kvarkush & erm Region, Krasnovishersk area, eastern slope of Kvarkush Plateau & $60^{\circ} 07^{\prime} \mathrm{N} 58^{\circ} 46^{\prime} \mathrm{E}$ \\
\hline & Ljaga & lic, Pech & $62^{\circ} 28^{\prime} \mathrm{N} 58^{\circ} 58^{\prime} \mathrm{E}$ \\
\hline & Molebny Kamen’ & Sverdlovsk Region, Ivdel area, eastern slope of Molebny Kamen' mountain & $61^{\circ} 14^{\prime} \mathrm{N} 59^{\circ} 20^{\prime} \mathrm{E}$ \\
\hline & Konzhakovski Kamen’ & Sverdlovsk Region, Karpinsk area, southern slope of Konzhakovski Kamen' mountain & $59^{\circ} 36^{\prime} \mathrm{N} 59^{\circ} 15^{\prime} \mathrm{E}$ \\
\hline & Denezhkin Kamen' & Sverdlovsk Region, Severouralsk area, Denezhkin Kamen' Nature Reserve & $60^{\circ} 26^{\prime} \mathrm{N} 59^{\circ} 29^{\prime} \mathrm{E}$ \\
\hline & Kumba & Sverdlovsk Region, Severouralsk area, southern slope of Kumba mountain & $60^{\circ} 08^{\prime} \mathrm{N} 59^{\circ} 39^{\prime} \mathrm{E}$ \\
\hline \multicolumn{4}{|c|}{ Sector IV WESTERN SIBERIA } \\
\hline & Ous & Sverdlo & $60^{\circ} 53^{\prime} \mathrm{N} 61^{\circ} 32^{\prime} \mathrm{E}$ \\
\hline 21 & Pelymski & , surrounds of Pelymski Tuman lake & $60^{\circ} 05^{\prime} \mathrm{N} 62^{\circ} 58^{\prime} \mathrm{E}$ \\
\hline & Njagan & Khanty-Mansi Autonomous District, Oktyabrsk area, su & $62^{\circ} 03^{\prime} \mathrm{N} 65^{\circ} 32^{\prime} \mathrm{E}$ \\
\hline & Khanty-Mansiysk & Khanty-Mansi Autonomous District, surrounds of Khanty-Mans & $60^{\circ} 59^{\prime} \mathrm{N} 69^{\circ} 03^{\prime} \mathrm{E}$ \\
\hline & Uim & Tyumen Region, Uvat area, $164 \mathrm{~km} \mathrm{E} \mathrm{of} \mathrm{Tobolsk} \mathrm{town,}$ & $58^{\circ} 51^{\prime} \mathrm{N} 71^{\circ} 07^{\prime} \mathrm{E}$ \\
\hline & Alexandrovskoye & Tomsk Region, Alexandrovskoye area, surrounds of Alex & $60^{\circ} 25^{\prime} \mathrm{N} 77^{\circ} 48^{\prime} \mathrm{E}$ \\
\hline & Sibirskiye Uvaly & $\begin{array}{l}\text { Khanty-Mansi Autonomous District, Nizhnevartovsk area, Nature park "Sibirskiye } \\
\text { Uvaly" }\end{array}$ & $62^{\circ} 24^{\prime} \mathrm{N} 81^{\circ} 42^{\prime} \mathrm{E}$ \\
\hline 27 & Bor & Krasnoyarsk Territory, Turukhansk area, surrounds of Bor village & $62^{\circ} 17^{\prime} \mathrm{N} 89^{\circ} 07^{\prime} \mathrm{E}$ \\
\hline \multicolumn{4}{|c|}{ Sector V CENTRAL SIBERIA } \\
\hline 28 & Mirnoye & $\begin{array}{l}\text { Krasnoyarsk Territory, Turukhansk area, Central-Siberian Nature Reserve, surrounds } \\
\text { Mirnoye village }\end{array}$ & $62^{\circ} 14^{\prime} \mathrm{N} 89^{\circ} 12^{\prime} \mathrm{E}$ \\
\hline 29 & Stolbovoy & $\begin{array}{l}\text { Krasnoyarsk Territory, Evenkia, Central-Siberian Nature Reserve, surrounds of } \\
\text { Stolbovoy cordon }\end{array}$ & $62^{\circ} 07^{\prime} \mathrm{N} 91^{\circ} 30^{\prime} \mathrm{E}$ \\
\hline 30 & Severo-Yeniseisk & Krasnoyarsk Territory, Severo-Yeniseisk area, surrounds of Severo-Yeniseisk town & $60^{\circ} 23^{\prime} \mathrm{N} 93^{\circ} 02^{\prime} \mathrm{E}$ \\
\hline 31 & Velmo & Krasnoyarsk Territory, Evenkia, surrounds of Velmo meteo st & $60^{\circ} 51^{\prime} \mathrm{N} 94^{\circ} 02^{\prime} \mathrm{E}$ \\
\hline 32 & Baikit & Krasnoyarsk Territory, Evenkia, surrounds of Baikit village & $61^{\circ} 39^{\prime} \mathrm{N} 96^{\circ} 18^{\prime} \mathrm{E}$ \\
\hline 33 & Vanavara & Krasnoyarsk Territory, Evenkia, Tungusky Nature Reserve & $60^{\circ} 23^{\prime} \mathrm{N} 102^{\circ} 17^{\prime} \mathrm{E}$ \\
\hline 34 & Strelka-Chunya & Krasnoyarsk Territory, Evenkia, surrounds of Strelka-Chunya village & $61^{\circ} 44^{\prime} \mathrm{N} 102^{\circ} 49^{\prime} \mathrm{E}$ \\
\hline 35 & Yerbogachen & Irkutsk Region, Yerbogachen area, surrounds of Yerbogachen village & $61^{\circ} 18^{\prime} \mathrm{N} 108^{\circ} 02^{\prime} \mathrm{E}$ \\
\hline \multicolumn{4}{|c|}{ Sector VI EASTERN SIBERIA } \\
\hline & Mirnyi & Yakı & $62^{\circ} 30^{\prime} \mathrm{N} 113^{\circ} 58^{\prime} \mathrm{E}$ \\
\hline 37 & Suntar & Yakutia Republic, Suntar area, surrounds of Suntar village & $62^{\circ} 13^{\prime} \mathrm{N} 117^{\circ} 41^{\prime} \mathrm{E}$ \\
\hline 38 & Namana & Yakutia Republic, Olekma area, $25 \mathrm{~km} \mathrm{~N}$ of Olekminsk Bala & $61^{\circ} 54^{\prime} \mathrm{N} 120^{\circ} 18^{\prime} \mathrm{E}$ \\
\hline 39 & Biryuk & Yakutia Republic, Olekma area, $15 \mathrm{~km} \mathrm{~N}$ of Biryuk village & $60^{\circ} 17^{\prime} \mathrm{N} 120^{\circ} 32^{\prime} \mathrm{E}$ \\
\hline 40 & Kysyl-Sy & Yakutia Republic, Vilyu area, $20 \mathrm{~km} \mathrm{NW}$ of Kysyl-Syr village & $63^{\circ} 57^{\prime} \mathrm{N} 122^{\circ} 21^{\prime} \mathrm{E}$ \\
\hline 41 & Buotoma & Yakutia Republic, Khangalas area, Lenskiye Stolby National Park & $61^{\circ} 15^{\prime} \mathrm{N} 128^{\circ} 47^{\prime} \mathrm{E}$ \\
\hline 42 & Yakutsk & Yakutia Republic, surrounds of Yakutsk town & $62^{\circ} 00^{\prime} \mathrm{N} 129^{\circ} 41^{\prime} \mathrm{E}$ \\
\hline 43 & Churapcha & Yakutia Republic, Churapcha area, surrounds of Churapcha village & $62^{\circ} 01^{\prime} \mathrm{N} 132^{\circ} 28^{\prime} \mathrm{E}$ \\
\hline
\end{tabular}


various world herbaria. As of 01.04.2020, this base included more than 84,000 units accumulated worldwide.

\section{Study sites description}

Since the early 1990s, the Institute of Plant and Animal Ecology UB RAS (Ekaterinburg) in cooperation with other institutions of Russia and the World conduct annual mycological studies in Siberia as part of the International TRANS-Siberian mycological expedition (Shiryaev \& Kotiranta 2015). Over a 30-years period, the middle boreal mycobiota has been studied best of all. But Siberia is vast and it is still problematic to visit each of its districts. Therefore, we developed a methodology for studying the spatial structure of mycobiota.

In general, the basic idea of approach was in unification of conditions of the material collection at each study site: the same number of collecting days (30), within the same total time period (within a period of the recent 20 years every study site is surveyed 3 times), the same area $\left(100 \mathrm{~km}^{2}\right)$. This gives a fairly clear picture of contemporary status of mycobiota. Therefore, it is possible to find how the actual diversity of fungi responds to the current climatic conditions. During the period of 20 years, dry and wet periods occurred repeatedly, and different fungi species responded to the wet periods by fruiting. Studies during the 3 years within 20 years time period increased a chance to catch the fruiting of the most species. This made possible to reveal the actual diversity of fungi under the current environmental and climatic conditions in particular locality nearly in full. The key points of the approach are described below:

1. Localities (area of $100 \mathrm{~km}^{2}$ ) for the study were chosen randomly and had the shape of a square $(10 \times 10 \mathrm{~km})$, or a circle (radius $5.6 \mathrm{~km}$ ). Variations of shape were allowed, for example, a rectangle $(20 \times 5 \mathrm{~km})$. Ideally, each locality was explored for 30 days by one researcher in 3 visits in different years during the past 20 years. Also, analysis involved all published to date data, information from various databases and herbaria. The network of routes in each locality was laid out in such a way as to cover the entire variety of typical biotopes in the zonal habitats typical to the region (consequently, localities with strong human impact and prevailing intra-zonal biotopes were excluded).

At the next step, the data were analysed for completeness, and some localities were excluded from analysis by the following criteria: 1) if the number of samples collected on the site was not less than $90 \%$ of the number of samples collected in the most well-studied study site in each continental sector; 2) if the largest area of study site was belonging to zonal habitat; 3) if the study site was not strongly affected by human activity. Localities not relevant to the above parameters are excluded from this study.

2. After the compilation, the potential list of species for each locality was verified. The following entries were excluded from the list: 1) recently described species as new to science, i.e., known only from locus classicus, or an extremely limited number of localities, although their distribution is potentially much wider, such as Ramaria cistophila, Ramariopsis robusta, Typhula suecica; 2) species with debatable taxonomic status: Ramaria altaica, Pterula caricis-pendulae; 3) species found in intra- and extrazonal habitats, but not on the zonal habitats under zonal conditions; 4) found only in the anthropogenic habitats and/or on the alien plants.

Thus, the aim was not to complete list of species at the national or regional level, but to make the lists of localities studied comparable in terms of climatic controls of mycobiota. However, the lists of species of fungi identified for localities (excluding the species unsuitable for analysis) comprised 85-100\% of mycobiota at regional level: $85 \%$ for the Republic of Yakutia, $91 \%$ for the Komi Republic, $94 \%$ for Khanty-Mansi Autonomous District, and $100 \%$ for the Republic of Karelia.

The results of mycobiota inventory for individual localities were published (Shiryaev 2004, Shiryaev \& Agafonova 2009, Kotiranta \& Shiryaev 2015, Shiryaev \& Kotiranta 2015, Shiryaev \& Kudashova 2015, Shiryaev \& Muzika 2015, Shiryaev \& Ruokolainen 2017). The list of fungal species for each locality is presented in Table 3 . The names of species and authors of taxa are given according to the IndexFungorum database (2020).

\section{Study sites description}

$\beta$-diversity was characterized using four parameters:

1) Whittaker index $(\beta \mathrm{w}=\gamma / \alpha-1)$ (Magurran 1988);

2) the average similarity for the species richness of fungi between all localities in each sector (Jacquard index, J) (Magurran 1988);

3) the speed of reaching the plateau of cumulative curves describing an increase in the number of species with an increase in the number of accounting units / individuals (the curves were approximated by the Michaelis-Menten (1913) equation, non-linear estimation), the rate constant is interpreted as the number of accounting units / individuals revealing half of all species of territory, i.e., the higher it is, the greater the $\beta$-diversity (CMM) (Trubina \& Vorobeichik 2012);

4) species-area relationship, estimated as the specific species richness representing the bilogarithmic form of the "species-area" relationship (constant Z from the Arrhenius (1921) equation).

The calculations are performed in the program EstimateS 10.2.

\section{RESULTS AND DISCUSSION}

The climate continentality index increases from the maritime Fennoscandian climate to the ultracontinental Yakutian along the studied middle boreal transect (Table 4). In the maritime climate of Fennoscandia, the Conrad's continental index averages $24 \%$, while in the ultracontinental climate, it reaches $88 \%$. The range of parameters within these continental sectors increases 2.5 times (from $19 \%$ to $51 \%$ ). Moreover, the maximum and minimum indicators differ almost 6 times (from $17 \%$ to $100 \%$ ). With an increase in the climate continentality, the mean annual temperature decreases. In study sites located in the maritime Fennoscandian climate, the mean annual temperature is $+3.5^{\circ} \mathrm{C}$, but in the ultracontinental climate - only $-7.2^{\circ} \mathrm{C}$, i.e., $10.7^{\circ} \mathrm{C}$ lower. It is equally important that the range of values between the minimum and maximum temperatures increases: in the maritime climate, the range is $33.9^{\circ} \mathrm{C}$, and 
Table 3. Species list of clavarioid fungi and their distribution along the middle boreal transect. The numbers of localities (1-43) are given according Table 2 .

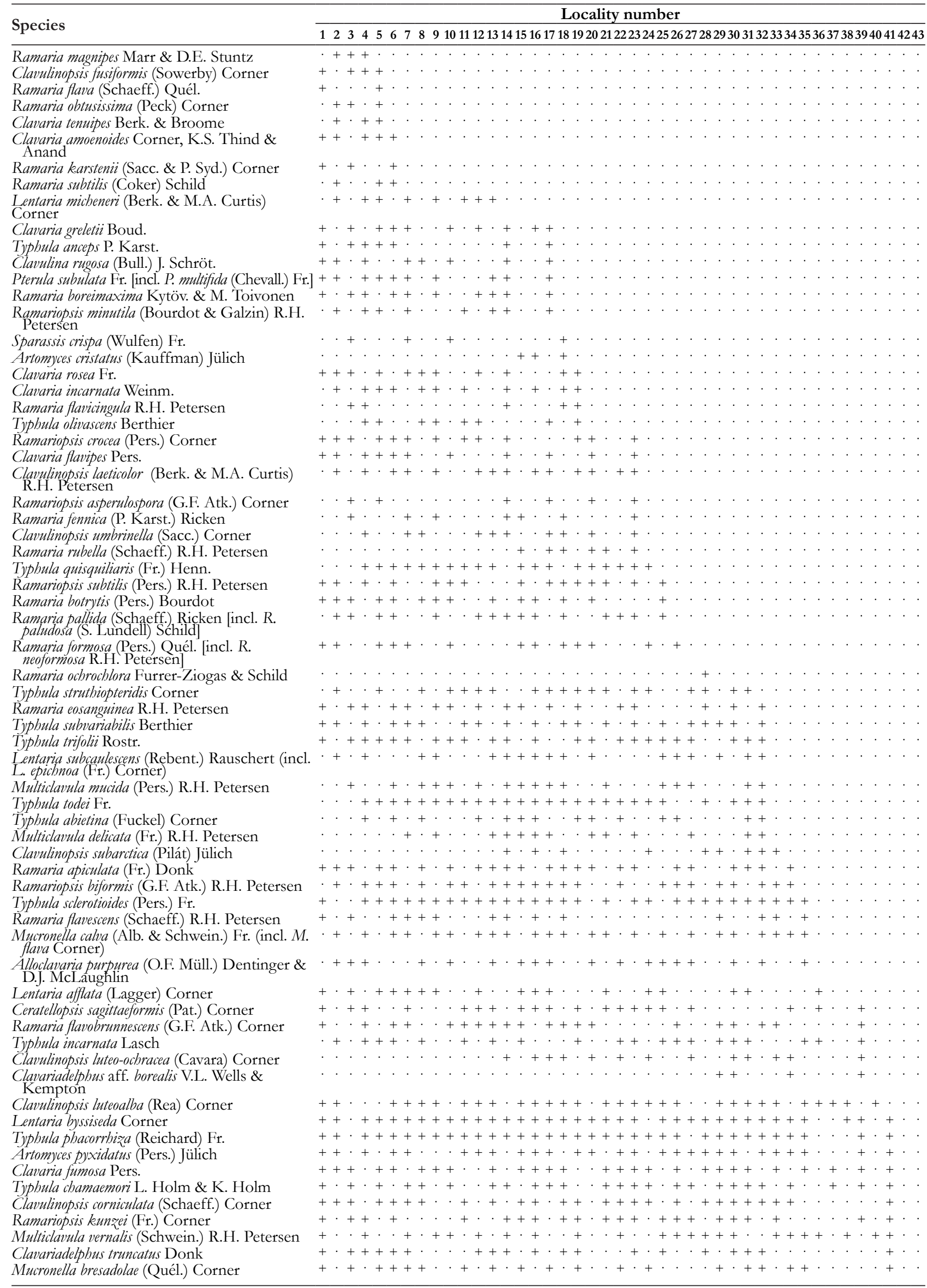


Table 3. Continued.

\section{Species}

Lentaria dendroidea (O.R. Fr.) J.H. Petersen Clavaria sphagnicola Boud.

Typhula umbrina Remsberg

Clavaria fragilis Holmsk.

Typhula caricina P. Karst.

Phaeoclavulina eumorpha (P. Karst.) Giachini

Clavaria argillacea Pers.

Clavariadelphus ligula (Schaeff.) Donk

Clavulina coralloides (Bull.) J. Schröt.

Phaeoclavulina abietina (Pers.) Giachini

Typhula graminum P. Karst.

Ramaria stricta (Pers.) Quél. [incl. R. comitis

Schild, R. concolor (Corner) R.H. Petersen] Clavicorona taxopbila (Thom) Doty

Ramaria gracilis (Pers.) Quél.

Ramaria suecica (Fr.) Donk

Ramariopsis tenuiramosa Corner

Typhula spatbulata (Corner) Berthier

Ramaria testaceoflava (Bres.) Corner

Clavariadelphus sachalinensis (S. Imai) Corner

Clavariadelphus pistillaris (L.) Donk

Ramariopsis pulchella (Boud.) Corner

Multiclavula corynoides (Peck) R.H. Petersen

Typhula culmigena (Mont. \& Fr.) Berthier

Typhula erytbropus (Pers.) Fr.

Typhula byalina

Typhula setipes (Grev.) Berthier

Typhula subbyalina Courtec.

Clavaria falcata Pers.

Typhula crassipes Fuckel

Typhula juncea (Alb. \& Schwein.) P. Karst.

Macrotyphula juncea

Typhula lutescens Boud.

Typhula micans (Pers.) Berthier

Pterulicium gracile (Desm. \& Berk.) Leal-Dutra

Dentinger \& G.W. Griff.

Typhula variabilis Riess

Clavulina cinerea (Bull.) J. Schröt.

Macrotyphula fistulosa

Typhula fistulosa (Holmsk.) Olariaga

Clavulinopsis helvola (Pers.) Corner

Phaeoclavulina corrugata (P. Karst.) J.H. Petersen

Typhula capitata (Pat.) Berthier

Phaeoclavulina flaccida (Fr.) Giachini

Typhula uncialis (Grev.) Berthier
Locality number

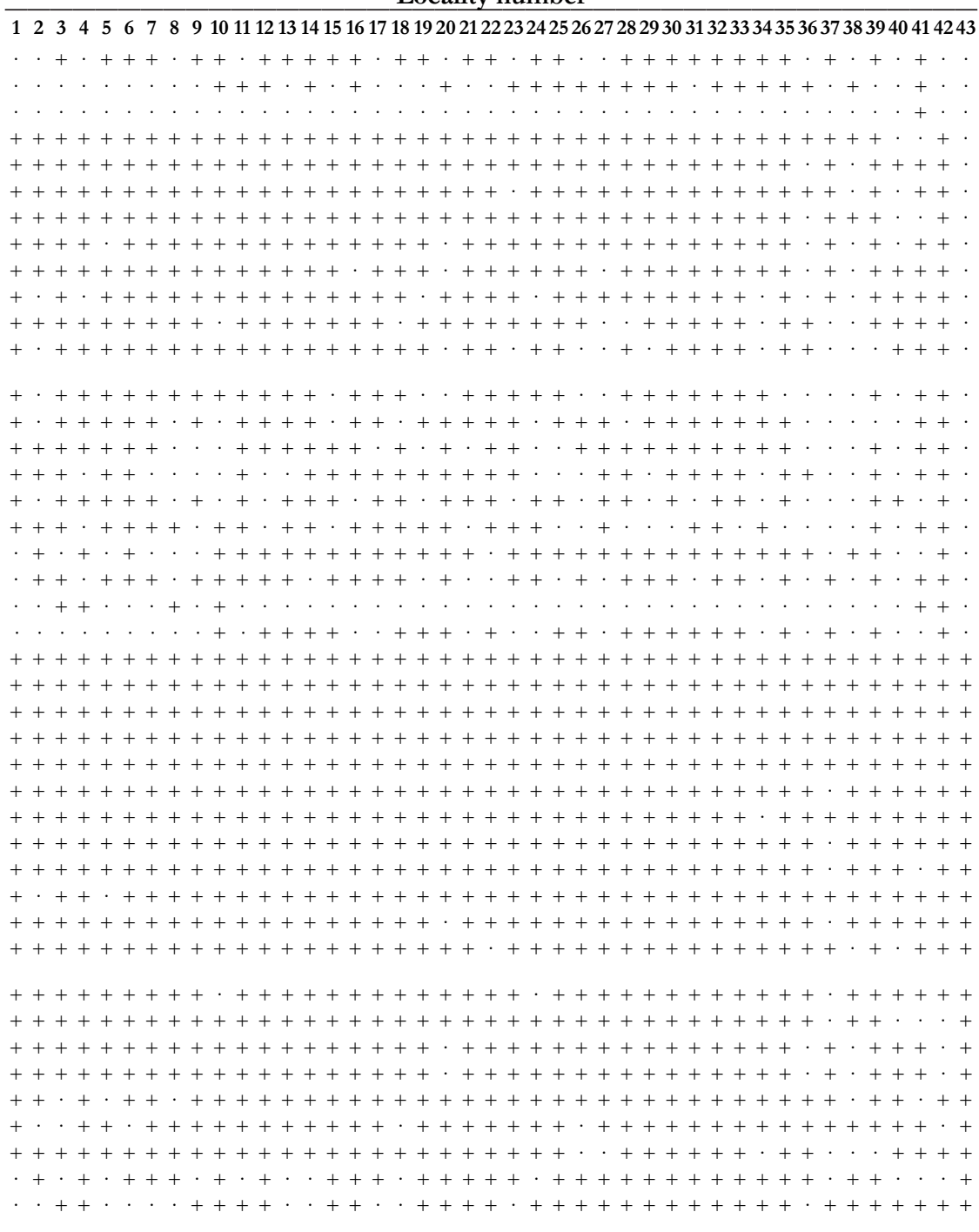

in the ultracontinental climate, it amounts to $74.5^{\circ} \mathrm{C}$, which is 2.2 times higher. The temperature difference at the soillitter interface is more than $63^{\circ} \mathrm{C}$ (decreasing from +23.4 to $-40.0^{\circ} \mathrm{C}$ ).

Due to the meso-hygrophilic nature of clavaroid fungi, their development is directly dependent not only on temperature indicators, but also on the level of atmospheric moisture. As continentality increases, the amount of precipitation and the relative humidity of air and litter decrease (Table 4). Thus, the average humidity of the litter decreases by $17 \%$ (from $83 \%$ to $66 \%$ ), and the range of values within the maritime and ultracontinental climate almost doubles (from $38 \%$ to $68 \%$ ). The difference between the maximum and minimum indicators is 3.5 times (from $100 \%$ to $29 \%$ ).

Thus, the bioclimatic conditions between the maritime and ultracontinental sectors vary significantly: the continentality index grows 5.5 times, while the range of the index inside the sectors increases 2.5 times, which indicates a very uneven distribution of this parameter. Temperature and relative humidity are 2-4 times lower in the cryoarid ultracontinental sector, and within each sector, the range of temperatures and humidity is large, which indicates an increase in the heterogeneity of conditions.

Extensive data has been accumulated over the 20-years period of our research indicates that the ultracontinental communities of clavarioid fungi are significantly poorer than their maritime and subcontinental zonal variants $(p=0.002)$. So, for clavarioid fungi communities developing in mid-boreal forests, for areas of $100000 \mathrm{~km}^{2}$ ( $\gamma$-diversity) from the maritime climate of the Gulf of Bothnia to the ultracontinental in Yakutia, species richness decreases by $40 \%$ : from 97 species in Fennoscandia to 59 species in Yakutia (Shiryaev 2014). At the same time, the geographical and ecological-morphological structure of mycobiota changes significantly: the share of widespread species in tundra, taiga, and steppe regions sharply increases with an almost complete absence of narrow areal and oceanic species. This distinguishes intracontinental "plain" mycobiota from maritime ones.

On the mesoscale, as climate continentality increases, species richness in localities decreases (Fig. 2). The richest locality including 74 species is situated in the maritime cli- 
Table 4 Distribution parameters of clavarioid fungi communities in the six sectors of climatic continentality of middle boreal subzone. Ic - continentality index; T - temperature; RH - relative humidity; $D$ - distance between localities; $\gamma$-diversity total number of species; $\alpha$-diversity - average number of species in localities; $\beta \mathrm{w}$ - Wittaker index; SD - standard deviation; $\mathrm{CV}$ - variation coefficient; $\mathrm{LV}$ - differences between the richest and poorest locality; $J$ - Jaccard index; $R$ - linear correlation coefficient between $\mathrm{J}$ and $\mathrm{D}\left(*-p<0.01{ }^{*}{ }^{\mathrm{ns}}-p>0.05\right) ; C_{\mathrm{MM}}-$ Michaelis-Menten equation ( \pm standard error); $Z-$ Arrhenius equation; $\mathrm{N}$ number of disappeared / appeared - number of species when moving to the next sector. All are mean parameters; in parentheses - minimum-maximum.

\begin{tabular}{|c|c|c|c|c|c|c|}
\hline \multirow{2}{*}{ Parameter } & \multicolumn{6}{|c|}{ Climate continentality sector } \\
\hline & I & II & III & IV & $\mathrm{V}$ & VI \\
\hline Ic. $\%$ & $24(17-36)$ & $35(30-53)$ & $49(37-62)$ & $62(48-79)$ & $72(50-87)$ & $88(49-100)$ \\
\hline T. ${ }^{\circ} \mathrm{C}$ & 3.5 & 2.2 & 0.5 & -1.1 & -4.0 & -7.2 \\
\hline $\mathrm{T} \max / \min .{ }^{\circ} \mathrm{C}$ & $23.4 /-10.5$ & 27.4 / -19.6 & $29.8 /-25.1$ & $30.5 /-29.8$ & $32.9 /-35.7$ & $34.5 /-40.0$ \\
\hline RH. \% & $83(62-100)$ & $77(56-100)$ & $80(45-100)$ & $77(48-100)$ & $70(42-98)$ & $66(29-97)$ \\
\hline area LK. km² & 600 & 700 & 600 & 800 & 800 & 800 \\
\hline & $189(83-580)$ & $353(81-850)$ & $140(35-321)$ & $542(120-1518)$ & $399(44-874)$ & $316(58-769)$ \\
\hline$\gamma$-diversity & 97 & 90 & 95 & 81 & 72 & 59 \\
\hline$\alpha$-diversity & $65.3(59-74)$ & $60.7(57-66)$ & $68.0(62-74)$ & $56.1(45-62)$ & $49.2(42-60)$ & $27.5(18-45)$ \\
\hline$\beta_{\mathbb{W}}$ & 0.48 & 0.48 & 0.39 & 0.44 & 0.46 & 1.14 \\
\hline SD & 5.3 & 3.9 & 4.4 & 4.0 & 5.6 & 8.5 \\
\hline CV. \% & 8.3 & 6.1 & 6.5 & 7.1 & 11.4 & 30.9 \\
\hline LV. \% & 25.4 & 15.8 & 19.3 & 15.4 & 42.8 & 138.9 \\
\hline$J$ & $0.61(0.69-0.55)$ & $0.65(0.73-0.59)$ & $0.59(0.69-0.51)$ & $0.69(0.79-0.55)$ & $0.54(0.64-0.40)$ & $0.30(0.46-0.20)$ \\
\hline$R$ & $-0.38^{*}$ & $-0.35^{*}$ & $-0.30^{*}$ & $-0.31^{*}$ & $-0.25^{*}$ & $-0.02^{\mathrm{ns}}$ \\
\hline$C_{\mathrm{MM}}$ & $238 \pm 19$ & $257 \pm 25$ & $252 \pm 28$ & $244 \pm 32$ & $289 \pm 40$ & $398 \pm 56$ \\
\hline$Z^{\mathrm{MM}}$ & $0.10(0.08-0.12)$ & $0.08(0.06-0.10)$ & $0.10(0.08-0.12)$ & $0.07(0.06-0.09)$ & $0.11(0.08-0.13)$ & $0.15(0.13-0.18)$ \\
\hline $\mathrm{N}$ disa & & 8 & 1 & 15 & 10 & 14 \\
\hline $\mathrm{N}$ appeared & & 1 & 6 & 1 & 1 & 1 \\
\hline
\end{tabular}

mate (Kivach), while in the poorest one, located in the ultracontinental sector (Churapcha), 4.1 times less species are identified (18). Between European sectors of continentality (I-III), with a maritime and subcontinental climates, the diversity of clavarioid fungi does not change significantly (74-57 species: the difference is 1.3 times only). Moreover, the $\alpha$-diversity within the Siberian continentality sectors (IV$\mathrm{VI}$ ) varies in a much wider range (from 18 to 62 species: the difference is 3.5 times). The border of a sharp separation of the species richness level for local fungal communities is located between the Urals and Western Siberia (Fig. 2). Therefore, results of the above multiscale studies of mycobiota showed that, as continentality increases, the number of species decreases for both scales, but the rate of decline is different. Thus, the $\gamma$-diversity is reduced 1.6 times (from 97 to 59 species), and the $\alpha$-diversity drops 2.4 times (from 65.3 to 27.5 species), that indicates a high spatial unevenness of the process of species elimination at different spatial scales, namely, a faster decrease in species richness at the meso- compared to the macro-level.

Since $\gamma$-diversity decreases more slowly compared to $\alpha$-diversity, the Whittaker's index in the ultracontinental sector is almost 3 times higher than in the maritime sector. The average similarity of species composition in Fennoscandia is 1.7-3.5 times lower than in Yakutia, and individual species richness increases 1.8-3.0 times, which also indicates a significant increase in $\beta$-diversity. The number of species in ultracontinental localities varies within a very wide range, therefore, differences between localities reach a maximum of $139 \%$, which is almost an order of magnitude higher compared to European sectors (15-25\%). Also in Yakutia, the coefficient of variation reaches maximum values $(31 \%)$ being 5 times more than its European counterparts. These examples indicate an extremely high spatial unevenness of the process of species extinction. The level of differences in the rate of cumulative curve output on the plateau is similar: in the ultracontinental sector, half of all species require a 1.7-2.5 times higher selective effort to be applied than in the marine sector, which is characterized by optimal climatic conditions.

Regardless of the assessment method, as continentality increases, $\beta$-diversity grows by $1.7-5$ times. Some localities in Yakutia have a Jaccard similarity index of only 0.20 , despite the small distances between them. The correlation of the similarity index with the distance between the localities weakens as climate continentality grows, and in the ultra-

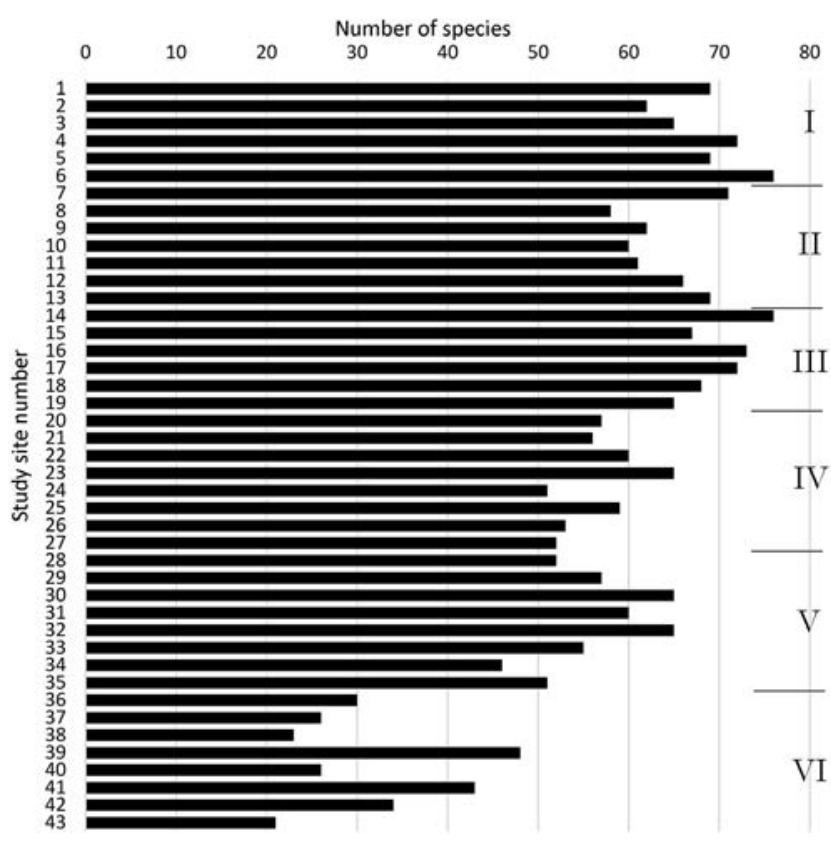

Figure 2 Species richness of clavarioid mycobiota in the 43 studied localities in the middle boreal subzone of Eurasia. Number of localities (1-43) and longitudinal sectors (I-VI) according Table 2. Localities are distributed along the increasing continental climate 
continental sector, it is completely absent, which confirms the mosaic nature of the mycobiota transformation and indicates an increase in the spatial isolation of local fungal communities.

The growth of climate continentality and heterogeneity of the environment play a key role in the formation of fungi diversity in ultracontinental Yakutia. It would seem that the ultracontinental East Siberian cryosemiaride climate (Nazimova \& Polikarpov 1996), with the widespread distribution of permafrost, boggy, and saline soils, with a wide spread of steppe landscapes, and a significant lack of rain moisture, should not support the existence of rich mycobiota. Nevertheless, on the hills, the soil warms up enough, which leads to thawing of permafrost, and the released moisture contributes to the development of a variety of rich boreal vegetation and mycobiota. Thus, within the cryosemiarid landscapes of Yakutia, extremely depleted areas unsuitable for the development of clavarioid fungi are adjacent to, and interspersed with relatively rich biotopes that ensure the existence of a wide range of species, although their number is reduced compared to the "optimal" conditions. This is confirmed by the fact that on the Prilensky Plateau of Central Yakutia, there are a number of localities (Buotoma, Biryuk), in which the level of species richness corresponds to the average richness of localities of Middle Siberia including the most heat-sufficient ones. Therefore, even in extreme conditions, some individuals are preserved in the "fragments" of suitable habitats, where, for various reasons, the conditions remain relatively favorable. A similar trend was found in tundra and forest-tundra zones, where the growth of $\beta$-diversity is 1.3-3.1 times (Shiryaev $2017,2018)$. This growth of $\beta$-diversity due to increasing spatial heterogeneity of environmental conditions occurs in other gradients, for example, latitudinal, altitude, and also when industrial pollution increases (Mukhin 1993, Trubina \& Vorobeichik 2012, Ordynets et al. 2018).

\section{CONCLUSIONS}

The initial hypothesis about the homogenization of the species composition of clavarioid fungi in the continental gradient was not confirmed: the rigidity and heterogeneity of the environmental conditions of the ultracontinental sector causes a decrease in the $\alpha$-and $\gamma$-diversity of the fungal communities, but the $\beta$-diversity increases, which can be interpreted as differentiation of the fungal communities. These results indicate that an increase in the harshness of conditions in the ultracontinental Yakutian sector leads to a sharp increase in the spatial isolation of local fungal communities on the mesoscale and almost complete loss of mycobiota integrity for clavariod fungi on a macroscale.

\section{ACKNOWLEDGEMENTS}

We thank the Russian Foundation for Basic Research (project № 18-05-00398 A) for financial supported.

\section{LITERATURE CITED}

Arrhenius, O. 1921. Species and area. Journal of Ecology 9(1):95-99.

Bocharnikov, M.V. 2015. Ecological-phytocoenotic structure of forest cover at the northern macroslope of the
Western Sayans. Lesovedenie. 1:10-19 (in Russian). [Бочарников М.В. Эколого-фитоценотическая структура месного покрова северного макросклона Западного Саяна // Аесоведение. 2015. № 1. С. 10-19].

Colwell, R.K. \& J.E. Elsensohn 2014. Estimate S turns 20: statistical estimation of species richness and shared species from samples, with non-parametric extrapolation. Ecography 37:609-613.

Fick, S.E. \& R.J. Hijmans 2017. WorldClim 2: new 1 km spatial resolution climate surfaces for global land areas. International Journal of Climatology 37(12):4302-4315.

Ignatov, M.S. 1993. Moss diversity patterns on the territory of the former USSR. Arctoa 2:13-45.

IndexFungorum 2020. At: http://www.indexfungorum. org. Last accessed 01.11.2020.

Kotiranta, H. \& A.G. Shiryaev 2015. Aphyllphoroidd fungi (Basidiomycota) in Tunguska River basin, Central Siberia, Russia. Karstenia 55(1-2):25-42.

Lomolino, M., B. Riddle, R. Whittaker \& J. Brown 2010. Biogeography, 4th ed. Sinauer, Sunderland, MA.

Magurran, A.E. 1988. Ecological diversity and its measurement. Princeton Univ Press, Princeton, 179 pp.

Mateo, R.G., O. Broennimann, S. Normand et al. 2016. The mossy north: an inverse latitudinal diversity gradient in European bryophytes. Scientific Report 6:25546.

Michaelis, L. \& M.L. Menten 1913. Die Kinetik der Invertinwirkung. Biochemische Zeitschrift 49:333-369.

Mordkovich, V.G. 2014. Steppe ecosystems, 2nd ed. GEO, Novosibirsk, 170 pp. (in Russian). [Мордкович В.Г. 2014. Степные экосистемы. 2-е изА. Новосибирск: ГЕО. 170 с.].

Mukhin, V.A. 1993. Biota of xylotrophic basidiomycetes of the West Siberian plain. Nauka, Ekaterinburg, 231 pp. (in Russian). [Myхин В.А. Биота ксилотрофных базидиомицетов ЗапаАносибирской равнины. Екатеринбург: Наука. 231 с.].

Nazimova, D.I. \& N.P. Polikarpov 1996. Forest zones of Siberia as determined by climatic zones and their possible transformation trends under global change. Silva Fennica 30(2-3):201-208.

Ordynets, A., J. Heilmann-Clausen, A. Savchenko, C. Bässler, S. Volobuev, O. Akulov, M. Karadelev, H. Kotiranta, A. Saitta, E. Langer \& N. Abrego 2018. Do plant-based biogeographical regions shape aphyllophoroid fungal communities in Europe? Journal of Biogeography 45(5):963-1207.

Rivas-Martínez, S., Sáenz, S.R. \& A. Penas 2011. Worldwide bioclimatic classification system. Global Geobotany 1:1-634.

Shiryaev, A.G. 2004. Clavarioid fungi of the Urals. Borealforest zone. Mikologia i Fitopatologia 38(4):59-72.

Shiryaev, A.G. 2007. Clavarioid fungi of the Urals. II. Nemoral zone. Karstenia 47(1):27-45.

Shiryaev, A.G. 2014. Spatial differentiation of clavarioid mycobiota in Russia: ecologo-geographical aspect, thesis of dissertation. Moscow State University, Moscow, 304 pp. (in Russian). Ширяев А.Г. 2014. Пространственная Аифференциация биоты клавариоидных грибов России: эколого-географический аспект. Аис. ... А-ра биол. наук. М.: МГУ, 304 с.].

Shiryaev, A.G. \& H. Kotiranta 2015. Aphyllophoroid fungi (Basidiomycota) of the middle part of Yenisei River basin, East Siberia, Russia. Karstenia 55(1-2):43-60.

Shiryaev, A.G. \& S.M. Muzika 2015. Aphyllphoroid fungi of the Middle Siberia: structure of local complexes on the 
middle boreal forests. Vestnik. Irkutskoy Gosudarstvennoy Selskohosyaistvennoy Academii 68:63-75 (in Russian). Ширяев А.Г., Музыка С.М. 2015. Афилмофоровые грибы Средней Сибири: структура цокальных комплексов средней тайги // Вестник ИрГХА. 68:63-75].

Shiryaev, A.G. \& N.N. Kudashova 2015. Biological diversity of aphyllophoroid fungi oif Tunguska Nature Reserve (Krasnoyarsk Kray, Evenkia district). Vestnik Irkutskoy Gosudarstvennoy Selskohozyaistvennoy Academii 71:69-85 (in Russian). Ширяев А.Г., Кудашова Н.Н. 2015. Биологическое разнообразие афилмофоровых грибов Тунгусского заповедника (Красноярский край, Эвенкийский район) // Вестник ИрГХА. Вып. 71. С. 69-85].

Shiryaev, A.G. 2017. Longitudinal changes of clavarioid fungi (Basidiomycota) diversity in the tundra zone of Eurasia. Mycology 8(3):135-146.

Shiryaev, A.G. \& A.V. Ruokolainen 2017. Clavarioid fungi of Kivach Nature Reserve: changes of diversity of middleboreal mycobiota along longitudinal gradient. Trudy Karelskogo Nauchnogo Centra RAN 6:48-60 (in Russian). Ширяев АГ., Руоколайнен А.В. 2017. Клавариоилные грибы заповедника Кивач: изменение разнообразия среднетаежной микобиоты в Аолготном градиенте / / Труды Карельского научного центра РАН. № 6. С. 48-60].

Shiryaev, A.G. 2018. Latitudinal changes of fungal diversity along model transect of Europe. Izvestiya RAN. Ser. geograficheskaya 3:56-66 (in Russian). [Ширяев А.Г. 2018. Широтные изменения разнообразия грибов на модельной трансекте Евразии // Известия РАН. Сер. геогр. № 3. C. 56-66].
Shiryaev, A.G. 2018. Spatial diversity of clavarioid mycota (Basidiomycota) at the forest-tundra ecotone. Mycoscience 59(4):310-318.

Shiryaev, A.G. \& O.V. Morozova 2018. Spatial distribution of species diversity of clavarioid mycobiota in West Siberia. Contemporary Problems of Ecology 11(5):514-526.

Skre, O., R. Baxter, R.M.M. Crawford, T.V. Callaghan \& A. Fedorkov 2002. How will the tundra-taiga interface respond to climate change? Ambio 12:37-46.

Talbot, S.S. \& W.J. Meades 2011. Circumboreal vegetation map (CBVM): Mapping the concept paper. CAFF Strategy Series Reports, № 3. CAFF Flora Group, Akureyri, Iceland.

Trubina, M.R. \& Ye.L. Vorobeichik 2012. The role of environmental heterogeneity in maintaining the diversity of small mammals in conditions of severe industrial pollution. Doklady Akademii Nauk 442(1):139-141 (in Russian). [Трубина М.Р., Воробейчик Е.А. 2012. Роль гетерогенности среды в сохранение разнообразия мелких млекопитающих в условиях сильного промышленного загрязнения // Аоклады Академии Наук. Т. 442, № 1. C. 139-141].

Tuhkanen, S. 1984. A circumboreal system of climatic phytogeographical regions. Acta Botanica Fennica. 127:1-50.

Urbanavichus, G.P. 2011. Specificy of the diversity of lichen flora in Russia. Izvestiya RAN. Ser. geograficheskaya 1:66-78 (in Russian). [Урбанавичюс Г.П. 2011. Особенности разнообразия михенофлоры России // Известия РАН. Сер. геогр. № 1. С. 66-78]. 